\title{
Molecular methods to evaluate effects of feed additives and nutrients in poultry gut microflora
}

\author{
Edgar O. Oviedo-Rondón ${ }^{1}$
}

${ }^{1}$ Department of Poultry Science, College of Agriculture and Life Sciences. North Carolina State University, Raleigh, NC 27695-7608. USA

\begin{abstract}
Intestines of each animal are the niche of a complex and dynamic ecosystem with important effects to the host. The members or final products of this ecosystem influence nutrient digestion, absorption, mucosa metabolism, general physiology, and local and systemic immunological responses of avian hosts. Better understanding of the avian gut microbial ecosystem may lead to improvements on poultry productivity, health, welfare, and reduction of food borne pathogens and the environmental impact of poultry production for a more sustainable industry. Molecular methods of microbial ecology are key tools to gain this knowledge. The objective of this presentation is to outline the basic concepts, applications, advantages, limitations, and evolution of these molecular methods used to study intestinal microbial ecology. The final goal is to stimulate their application in poultry applied research and development of new feed additives. Some practical examples in poultry research will be described to illustrate their relevance to advance in control methods for pathogens, avoid or manage disbiosis or subclinical intestinal diseases, reduce environmental impact, elucidate effects of nutrients in gut mucosa, microflora, and in general to improve poultry performance.
\end{abstract}

Key Words: intestinal microbial ecology, nutrition, molecular methods

\section{Metodologias moleculares para avaliar efeitos de aditivos e nutrientes na microflora intestinal das aves}

\begin{abstract}
RESUMO - O intestino de cada animal é o nicho de um ecossistema complexo e dinâmico com efeitos importantes para o hospedeiro. As comunidades microbianas componentes deste ecossistema e/ou os produtos finais do metabolismo influenciam a digestão e absorção de nutrientes, o metabolismo das mucosas, a fisiologia geral e as respostas imunitárias locais e gerais da ave hospedeira. A melhor compreensão do ecossistema microbiano do intestino das aves pode levar a melhorias na produtividade, saúde, bem estar, e redução de agente patogênicos dos alimentos e do impacto ambiental da produção avícola para uma indústria mais sustentável. Os métodos moleculares da ecologia microbiana são ferramentas chaves para obter este conhecimento. O objetivo desta apresentação é descrever os conceitos básicos, aplicações, vantagens, limitações, e evolução destes métodos moleculares usados para estudar a ecologia microbiana do intestino. A meta final é estimular sua aplicação em pesquisa avícola aplicada e desenvolvimento de novos aditivos para alimentos. Alguns exemplos práticos em pesquisa avícola serão descritos para ilustrar sua relevância para avançar em métodos de controle de agentes patogênicos, evitar ou manejar a disbiose ou doenças intestinais sub-clínicas, reduzir o impacto ambiental, esclarecer os efeitos dos nutrientes na mucosa intestinal, a microflora e, em geral, melhorar o desempenho das aves.
\end{abstract}

Palavras-chave: ecologia microbiana do intestino, métodos moleculares, nutrição

\section{Introduction}

Poultry and other animals, as well as humans, live in environments where microbes are ubiquitous. The microbes associated with mucosal surfaces exceed the total number of somatic and germcells by more than an order of magnitude in any animal. The gastrointestinal tract (GIT) is home to the most complex and populous society or ecosystem of microbes. Dynamic ecosystems exist within the different segments of the gut, each one having distinct luminal and mucosal niches. Countless diverse microbial communities (MC) composed of bacteria, protozoa, fungi, yeasts, bacteriophage and other virus, within the different enteric niches are affected by the flow of nutrients from the diet, secretions from the host and the systemic responses of the host (animal) dictated by its immune, endocrine and nervous systems (Dibner \& Richards, 2004, Thompson \& Applegate, 2005, Korver, 2005, Oviedo-Rondón, 2006). 
Microbes have profound effects in some of the physiological processes of their animal host (Ewing \& Cole, 1994; Fuller \& Perdigon, 2003). Digestive microflora populations affect broiler and layer hen performance and health (Apajalahti \& Bedford, 1999; Hume et al., 2003, 2006; Oviedo-Rondón et al., 2006; Parker et al., 2007). These effects in the host may be due primarily to the complex interactions that influence the intestinal environment, and the development and responses of the host immune system against pathogenic and non-pathogenic antigens (Cebra, 1999; Kelly \& Conway, 2005). Since all those complex associations cannot be simulated in laboratory conditions, molecular techniques have been used more frequently in research to take snapshots of the status of these dynamic relations and in this way advance in the understanding of these ecosystems. The first important step in studying an ecosystem is to identify its members, and the second is to link their presence with their activity and the role that the different organisms play in establishing and maintaining a well-functioning ecosystem. Currently, most of the work is directed on identifying the MC present in the gut on specific circumstances. Much more work is necessary to identify functions, relations among MC and with the host.

The strongest determinant of the gut microbial profile is the host's diet. Factors such as diet composition, nutrient concentration, feed physical traits, feed processing, and feed additives play significant roles in the dynamics of gut microflora (Apajalahti et al., 2001, 2004; Guo et al., 2004, Hume et al., 2003, 2006; Oviedo-Rondón et al., 2006; Parker et al., 2007, Nalian et al., 2009). Apajalahti et al. (2001) used molecular methods to survey MC of broilers raised at eight commercial poultry farms in Finland. These birds were fed different commercial wheat-based diets, some with locally added whole wheat. This survey covered different seasons (spring and fall) and years (1997, 1998, and 2000). They found that diet was the strongest individual determinant of the total MC structure in the ceca of broiler chickens, whereas profiles of individual farms with identical feed regimes hardly differed from each other. In this study, there was also no significant variation of the colonic microbial community due to season or year

The understanding and monitoring of the dynamics of gut microbial ecology are important for the development of alternative methods or products to modulate the MC to either improve performance or reduce the effects of stress or disease. Additionally, it may be helpful to improve the control of food borne pathogens, manage microflora to reduce production of ammonia and volatile fatty acids (VFA), responsible for noxious odors in poultry houses.
This means that the study of MC have impacts on production, health, welfare, food safety, and reduction of the environmental impact of poultry.

In this presentation, I aim to outline the basic concepts, applications, advantages, limitations, and evolution of these molecular methods used to study intestinal MC in order to stimulate their application in poultry applied research. Some practical examples in poultry research will be described to illustrate their importance to advance in control methods for pathogens, avoid or manage disbiosis or subclinical intestinal diseases, reduce environmental impact, clarify effects of nutrients in mucosa, microflora, and improve performance in poultry.

Importance of studying gut microbes in poultry butrition

The importance of understanding the dynamics of intestinal microbial ecology have been recognized for a long time (Savage, 1977). Understanding the dynamics of gut MC is necessary to establish or develop strategies to improve feed efficiency and growth rate (Apajalahti \& Bedford, 1999; Hays, 1991), avoid intestinal diseases and proliferation of food borne pathogens (Hume et al., 2003), identify better feed additives and nutrient levels that influence beneficial MC (Hume et al., 2006; Oviedo-Rondón et al., 2006; Parker et al., 2007, Nalian et al., 2009).

Gut microflora aid in colonization resistance, competition for intestinal attachment sites, and aid in the early development and stimulation of the immune system (Bar-Shira \& Friedman, 2005; Bar-Shira et al. 2005). The first line of defense against pathogens is the normal gut microflora. Many of the commensal bacteria produce organic acids such as lactic, propionic and butyric, and compounds known as bacteriocins that effect both Gram-positive and Gram-negative bacteria. Reuterin, a bacteriocin produced by Lactobacilli, has been shown in vitro to be inhibitory against Salmonella, Shigella, Clostridium and Listeria (Naido et al., 1999). Other compounds produced by commensal bacteria are hydrogen peroxide and short chain fatty acids (SCFA). Hydrogen peroxide results in the peroxidation of lipid membranes, and increased bacterial membrane permeability. The SCFA are predominately the VFA, acetic, propionic, and butyric acids. These are the end products of fermentation shown to be biological indicators of a healthy microbial ecosystem, as well as having inhibitory effects on Salmonella colonization in chickens (Nisbet et al., 1996).

The microbial profile in this intestinal ecosystem is influenced by the host animal's responses to control the bacterial proliferation within their intestines using several different physiological mechanisms (Oviedo-Rondón, 
2006). The main intestinal barriers to pathogen infection include peristalsis (flow rate, transit time), secretions (water, electrolytes, $\mathrm{HCl}$, enzymes, bile salts, mucins and immunoglobulin A, IgA), mucus (physical properties, associated micro flora, $\operatorname{IgA}$ ), mucosal integrity and the gut associated lymphatic tissue (GALT). Additionally, nutrient absorption by the host animal is highly competitive with enteric microflora by limiting substrates, while the high passage rates of digesta and continuous sloughing of the epithelial cells and mucus washes out adhered bacteria. In addition to the polymeric immunoglobulin receptor on mucosal epithelial cells, IgA antibodies can bind to receptors on a variety of leukocytes, which can activate the alternative complement pathway, making IgA antibodies potential participants in inflammatory reactions. Consequently, these interactions are responsible for part of the immunological responses observed with some diets and specific nutrients.

Any perturbation of the enteric ecosystem by changes in general immunity or gut physiology of the bird, temperature stress (heat or cold) or diet composition, can cause disbacteriosis and/or enteritis associated with lower absorption of nutrients by the host. Exposure to stress hormones, norepinephrine and epinephrine, significantly increases the proliferation of several enteropathogenic bacteria such asEscherichia coli, Yersiniaenterocloitica, Pseudomonas aeurinosa, Salmonella enteritidis, Salmonella cholerasuis, Salmonella typhimurium (Thompson \& Applegate, 2005). Even under the best nutritional conditions, environmental stresses under commercial production conditions can increase intestinal bacteria proliferation and make broilers more propense to enteric problems. The changes in intestinal motility, modifications of gastric acidity, decreases in the production of bacteriostatic peptides in the pancreas, alteration in the amounts of mucus produced or in its composition, reduced IgA secretion, and focal ulcerations of mucosa result in failure of nutrient absorption, tissue necrosis, and shifts in gut microflora populations, numbers and metabolism. Drastic qualitative and quantitative changes in the gut microflora characteristics are called dysbiosis, dysbacteriosis, and even small intestinal bacterial overgrowth (SIBO). These events generally cause clinical signs, such as flushing (diuresis or diarrhea). These events generate humid litter that may affect the air quality of the house with higher production of ammonia, and higher incidence of respiratory problems.

It has been proven that is possible to shift the MC from pathogenic to beneficial bacteria by changing the dietary composition of ingredients (Gibson \& Roberfroid, 1995;
Collins \& Gibson, 1999) or using feed additives (OviedoRondón et al., 2006; Hume et al., 2006; Parker et al., 2007, Nalian et al., 2009). Diet composition, amounts of digesta reaching each section of the intestine, passage rate, enzyme production and secretions change as the chicken age. The MC evolves in the intestinal ecosystems as the birds age following the changes in physiological, immunological characteristics and feeding behavior (Hume et al., 2003; Lu et al., 2003). This process is known as microbial succession.

The MC can also change in periods of hours. For example, Thompson et al. (2008) using molecular methods were able to observe that feed withdrawal in broilers alters the $\mathrm{MC}$ of the intestine by decreasing bacterial diversity in the ileum. Some feed additives and mineral levels can help to maintain similar $\mathrm{MC}$ in regions of the guts of broilers independently of feed withdrawal (Thompson et al., 2008, Hume et al., 2003), intestinal infections with coccidia (OviedoRondón et al., 2006; Hume et al., 2006; Parker et al., 2007; Nalian et al., 2009), or heat stress (Lan et al., 2004).

Despite its importance, very little is known about the molecular mechanisms that allow components of the microflora to interact with their hosts so as to establish relationships that are advantageous to both. Understanding such relationships is important in elucidating the origins of opportunistic infections that can cause common poultry diseases such as necrotic enteritis and colibacillosis, or increase the negative impact of parasite infections like in coccidiosis, and even the propagation of antibiotic-resistant organisms or resistance to other growth promotant products.

\section{Feed additive effects on $M C$}

Growth promotant antibiotics are well known for the inhibition of undesired MC and the negative effects of their metabolites (Anderson et al., 1999; Van Immerseel et al., 2004), and selection for beneficial bacteria (Collier et al., 2003; Engberg et al., 2000). Other products have been proposed as alternatives to growth promotant antibiotics utilization (Thomke \& Elwinger, 1998) taking in consideration the increasing bacterial resistance to some antibiotic categories, ban of its use in some countries, and poultry consumer rejection.

Alternative new feed additives have been classified as probiotics, prebiotics, enzymes, organic acids, and herb extracts. Probiotics introduce desirable live microorganisms into the GIT. Prebiotics promote the growth of desirable bacteria in the GIT (Patterson \& Burkholder, 2003). The enzymes help to eliminate the anti-nutritional effects of water-soluble polysaccharides, and/or change the substrates 
to improve proliferation of some beneficial MC while organic acids cause the inhibition of bacterial growth. Finally, the herb extracts have very variable working mechanisms that depend on the composition (bacteriostatic or immunestimulating. One category of these herb extracts is the specific essential oil (EO) blends. These products are mixtures of phytochemical compounds, such as carvacrol, thymol, cinnamaldehyde among others, with selective antimicrobial properties (Lee et al., 2004). Some specific EO blends have shown promising results towards the reduction of Clostridium perfringens colonization and proliferation, control of coccidia infection and consequently may help to reduce NE (Oviedo-Rondón, 2006).

The combination of probiotics and prebiotics has been called sinbiotics. Each type of product has demonstrated varied efficacy while administered independently or in combinations, but some evidence suggests the combination or dual administration of prebiotics and probiotics might be more effective (Langhout, 2000).

The gut MC are also affected by enteropathogen infections such as those caused by Eimeriaspp. Apajalahti (2004) indicated that infection withEimeria maxima changes $\mathrm{MC}$ and the patterns of fermentation in the ilea and ceca of broilers. This suggests that when the coccidiostats are not used in the diets or coccidian vaccines are administered, gut MC are different and during coccidiosis outbreaks that microbial succession is less stable affecting physiology and nutrient utilization (Hume et al., 2003; Oviedo-Rondón et al., 2006; Parker et al., 2007; Nalian et al., 2009).

\section{Nutrient effects on MC and interaction with host}

The understanding of the interactions between diet composition, microbiota, intestinal physiology, and immunology is important to develop novel technologies, nutritional manipulations, and management systems to optimize bird growth.

Most of the gut microbiota competes with the host for nutrients by various means. Competition for nutrient resources from pathogenic microbiota is to the detriment of the host animal. This non-symbiotic microflora may 1) produce toxic phenolic/aromatic metabolites that increase cell mucosa turnover; 2) increase mucus production; 3 ) cause deconjugation of bile salts that reduces fat digestion; 4) increase protein and energy needs to maintain gut function and health; and 5) reduce growth efficiency. High levels of the common bacterial toxic metabolites, such as ammonia, phenol, 4-methylphenol (p-cresol), 4-ethyphenol, indole and 3-methylindole (skatole), and biogenic amines, can cause or exacerbate enteritis (Gaskins et al., 2002). These compounds are responsible for noxious odors and air pollution caused by poultry manures. The appropriate manipulation of gut MC may help to reduce this environmental impact.

Competition for nutrient resources from commensal or symbiotic microbiota benetit the host by 1) promotion of gut maturation; 2) enhancement of gut integrity; 3) antagonisms against pathogens (competitive exclusion); and 4) immune modulation. The symbiotic microflora also plays a significant role in maintaining intestinal immune homeostasis by preventing inflammation (Lanet al.,2005). Increasing the numbers of these types of bacteria and providing the appropriate substrate for their proliferation and metabolism improves the efficiency of nutrient utilization by the host.

Cecal symbiotic bacteria have important and specific metabolic, trophic and protective functions. Metabolic functions include fermentation of non-digestible dietary residue and endogenous mucus, which is important for the recovery of energy as SCFA, production of vitamin K, and absorption of ions. Symbiotic bacteria influences epithelial cell proliferation and differentiation due to their production of SCFA, and they also positively influence the development and homoeostasis of the immune system. The attachment of non-pathogenic bacteria to the brush border of intestinal epithelial cells can prevent the attachment and subsequent entry of pathogens. Symbiotic bacteria also competitively exclude pathogenic bacteria by competing for available nutrients, by producing bactericins, or maintaining their habitat by consuming resources of the gut and secreting compounds that are inhibitory to pathogens.

The dietary levels of specific nutrients such as fat (Knarreborg et al., 2002), protein (Parker et al., 2007) calcium and zinc (Hume et al., 2003) and $\mathrm{pH}$ of the diet (Dibner \& Richards, 2004) have been associated with shifts in MC. The association of dietary glycine supplementation with $\mathrm{C}$. perfringens numbers and location, $\alpha$-toxin production and gut lesionscores has recently been reported (Dahiya et al., 2005).

\section{Molecular methods to study intestinal microbial ecology}

The traditional methods of gut microbial diversity and ecology were largely based on classical anaerobic culture techniques, phenotypic characterization of culturable isolates, and light and electron microscopy. However, the real complex and diverse digestive microflora cannot be studied accurately with these methods because only $1 \%$ of all MC are culturable (Hugenholtz et al., 1998). Culturebased enumeration and characterization techniques also have three major problems, the inevitable bias introduced by the selective culture media, the lack of a phylogenetically 
based classification scheme, and the unfeasibility to detect of unculturable and fastidious bacterial species or those present in very low abundance.

The utilization of molecular techniques has improved the analysis of complex intestinal MC in animals and especially in poultry (Apajalahti et al., 2001, 2004; Lu et al., 2003; Van der Wielen et al., 2002; Hume et al., 2003, 2006; Oviedo-Rondón et al., 2006; Parker et al., 2007, Nalian et al., 2009).

\section{Detection and phylogenetic identification of $M C$}

Modern molecular ecology techniques based on sequence comparisons of nucleic acids (DNA or RNA) are used to provide molecular characterization while at the same time providing a classification scheme that predicts natural evolutionary relations. In principle, nucleic acid probes can be designed to hybridize with a complementary target sequence and thus provide a complete description independent of the growth conditions and the culture media used. The most common methods used in molecular microbial ecology are outlined in Table 1.

\section{Compilation-based and total community analyses}

The molecular MC analysis methods can be classified into two general classes: 1) Compilation-based analyses and 2) Total community analyses (Holben et al., 2004). The compilation-based analyses often involve a random "shotgun" approach, wherein related functional or ribosomal RNA (rRNA) gene sequences from individual community members are amplified by polymerase chain reaction (PCR) and cloned or sequenced from total community DNA for phylogenetic analysis or comparison to existing databases. Compilation analyses combine individual information of MC to obtain a sense of community profile. In contrast, the total community analyses characterize the whole community structure or diversity through a single, more direct analysis of total community DNA and classifies according to relative abundance percentages of DNA bases. The most common method is the fractionation of total community DNA based on $\mathrm{G}+\mathrm{C}$ content (Holben et al., 2004).

\section{Sequencing of rRNA gene}

In compilation-based analyses the microbes are identified based upon differences in their $16 \mathrm{~s}, 23 \mathrm{~s}$, and $5 \mathrm{~s}$ rRNA (Schmidt, 1994). In the initial step, the DNA can be extracted from digesta samples and then restricted into discrete-sized fragments using specific restriction enzymes such as PUV II, PST I, and ECHO RI. The DNA is then transferred to a membrane and probed with a region of the

Table 1 - Overview of the current culture-independent approaches to studying microbial ecology

\begin{tabular}{|c|c|c|c|}
\hline Approach & Target & Outcome experiment & Main limitations \\
\hline \multicolumn{4}{|l|}{ Sequencing of rRNA genes } \\
\hline $16 \mathrm{~S}$ rRNA gene sequencing & 16S rRNA gene & $\begin{array}{l}\text { 16S rRNA gene sequence } \\
\text { collection }\end{array}$ & $\begin{array}{l}\text { Bias in NA extraction, } \\
\text { PCR and cloning; laborious }\end{array}$ \\
\hline RT-PCR & mRNA & Specific gene expression & $\begin{array}{l}\text { Bias in NA extraction } \\
\text { and RT-PCR }\end{array}$ \\
\hline $\begin{array}{l}\text { Fingerprinting DDGE, TGGE, } \\
\text { TTGE, T-RFLP, SSCP }\end{array}$ & 16S rRNA gene & Diversity profiles & Bias in NA extraction and PCR \\
\hline Non-16S rRNA gene fingerprinting & $\begin{array}{c}\text { GC fractionation of } \\
\text { DNA; cellular fatty acids }\end{array}$ & Diversity profiles & $\begin{array}{l}\text { 16S rRNA approaches required } \\
\text { for identification }\end{array}$ \\
\hline \multicolumn{4}{|c|}{ Quantification of $16 S$ rRNA and its encoding genes } \\
\hline Dot-blot hybridization & $16 \mathrm{~S}$ rRNA & $\begin{array}{l}\text { Relative abundance } \\
\text { of } 16 \mathrm{~S} \text { rRNA }\end{array}$ & $\begin{array}{l}\text { Laborious at species level; } \\
\text { requires } 16 \mathrm{~S} \text { rRNA gene sequence data }\end{array}$ \\
\hline qReal-time PCR & $16 \mathrm{~S}$ rRNA gene & $\begin{array}{l}\text { Relative abundance } \\
\text { of } 16 \mathrm{~S} \text { rRNA genes }\end{array}$ & $\begin{array}{l}\text { Laborious and expensive } \\
\text { in early stages of development }\end{array}$ \\
\hline FISH & $16 \mathrm{~S}$ rRNA & $\begin{array}{c}\text { Enumeration of bacterial } \\
\text { populations }\end{array}$ & $\begin{array}{l}\text { Laborious at species level; } \\
\text { requires } 16 \mathrm{~S} \text { rRNA gene sequence data }\end{array}$ \\
\hline \multicolumn{4}{|l|}{ DNA microarray technology } \\
\hline Diversity arrays & $\begin{array}{l}\text { 16S rRNA genes; antibiotic } \\
\text { resistance genes }\end{array}$ & Diversity profiles & $\begin{array}{l}\text { Laborious; expensive; in early } \\
\text { stages of development }\end{array}$ \\
\hline DNA microarray & mRNA & Transcriptional fingerprints & $\begin{array}{l}\text { Bias in NA extraction and } \\
\text { NA labeling; expensive }\end{array}$ \\
\hline Parallel sequencing technologies & $\begin{array}{l}\text { Hundreds to thousands } \\
\text { of genes }\end{array}$ & Sequence of microbial genome & $\begin{array}{l}\text { Cost, sequences to compare } \\
\text { and identify correctly }\end{array}$ \\
\hline
\end{tabular}

Source: Adapted from Zoetendal \& Mackie (2005). 
rRNA to reveal the pattern of rRNA genes. This pattern is known as the fingerprint of the bacterium. Most phylogenetic information from the GIT has been collected by sequencing of cloned 16S rRNA gene amplicons of V3 and V8 regions of the bacteria's genome that have been obtained by PCR. The more conserved regions are used as targets for universal probes that react with all living organisms in the gut digesta samples for discriminating between broad phylogenetic groups such as the domains Archaea, Bacteria, and Eucarya. The more variable sequence regions generate a fingerprint that can be used to classify microbes at the genus and the species level, and sometimes even at the strain level with specific hybridization probes. Franks et al. (1998) showed that about two thirds of the known MC could be identified using specific molecular probes.

The pattern of rRNA genes is used to create the clone library. The sequences of the cloned amplicons are determined and compared with the available sequences in the DNA databases (genbank, National Animal Genome Research Program, NAGRP), followed by phylogenetic analysis. The databases contain over 185 different genera and many different species of bacteria. Some examples of bacteria associated with foodborne illness in the databases are as follows: Listeria (105 pattern types), Salmonella (605 pattern types), Escherichia (158 pattern types) and Staphylococcus (611 pattern types).

Bioinformatics and appropriate statistical analyses of sequences and data are very important for adequate identification of MC and interpretation of lab analyses. Compilation-based approaches, which typically analyze 100 to 300 randomly obtained individual sequences, are laborious, expensive and limited in their ability to accurately detect total diversity where communities are complex. Thus, in MC comprised of hundreds to thousands of individual taxa (e.g., soils or the GIT), individual taxa present in lower abundance (i.e., minority populations) will go undetected. Some recent studies of microbial diversity have taken a theoretical approach by estimating total community diversity based on mathematical extrapolation from a partial analysis of the total community (Hughes et al., 2001; Martin, 2002). These approaches, however, provide no specific information regarding the identity of minority populations, since their presence is only inferred and no clones or real DNA sequences are actually obtained and analyzed.

The sequencing of rRNA gene libraries have several problems such as the lack of consistency among labs and between the molecular procedures (i.e. nucleic acids isolation, PCR), which complicates comparisons of data from different studies. More importantly, the thresholds used for operational taxonomic unit (OTU) determination vary from $1 \%$ to $5 \%$ sequence differences (Martin, 2002). This indicates that diversity estimates are very subjective. In addition, it has been demonstrated that source tracking of $16 \mathrm{~S}$ rRNA genes is impossible because of these inconsistencies, as sequence depositions rely on the OTU determination and the researcher's opinion (Zoetendal et al., 2004). Another problem concerned with the analysis of $16 \mathrm{~S}$ rRNA gene clone libraries concerns the biases introduced by PCR and cloning, from which the OUT determination is frequently underestimated.

The ribosomal intergenic spacer analysis (RISA) is one of the methods to compare MC. It involves PCR amplification of a region of the rRNA gene operon between the small (16S) and large (23S) subunits called the intergenic spacer region. These fragments are extremely variable in both sequence and length for the different prokaryotic species, due to the presence of several functional units within them such as tRNA genes. The resulting PCR product is a mixture of fragments contributed by several dominant community members. This product is electrophoresed in a polyacrylamide gel, and the DNA is visualized following staining. The result is a complex banding pattern that provides a community-specific profile, with each DNA band corresponding to a bacterial population on the original assemblage

\section{$16 S$ rRNA gene fingerprinting}

Fingerprinting of 16S rRNA genes is more suitable for monitoring communities' shifts or comparing different MC. The techniques normally used are: 1) Denaturing gradient gel electrophoresis (DGGE) (van der Wielen et al., 2002; Hume et al., 2003, 2006, ; Oviedo-Rondón et al., 2006); 2) Temperature gradient gel electrophoresis (TGGE) and temporal temperature gradient gel electrophoresis (TTGE); 3) Single-strand conformation polymorphism (SSCP) and terminal-restriction fragment length polymorphism (T-RFLP) (Gong et al., 2002; Marsh et al., 2000; Lan et al., 2004). All these fingerprinting techniques are all PCRbased, and their respective profiles represent the sequence diversity within ecosystems. For more detailed descriptions of these fingerprinting techniques, refer to the review papers by Muyzer \& Smalla (1998) and Vaughan et al. (2000). Software has been developed to analyze fingerprinting data, compare between communities, and calculate similarity indices or coefficients by analysis of clustering profiles. These fingerprinting approaches are not quantitative, as PCR is involved. However, the possibility of absolute quantification of targets resulting in single amplicons in 
TGGE profiles has been demonstrated. A similar quantification approach was performed by combining constant-denaturant capillary electrophoresis (CDCE) and uantitative PCR (Zoetendal \& Mackie, 2005).

Denaturing gradient gel electrophoresis (DDGE) works by applying a small sample of DNA (or RNA) to an electrophoresis gel that contains a denaturing agent. Certain denaturing gels are capable of inducing DNA to melt at various stages. As a result of this melting, the DNA spreads through the gel and can be analyzed for single components, even those as small as 200-700 base pairs. Rather than partially melting in a continuous zipper-like manner, most fragments melt in a step-wise process. Discrete portions or domains of the fragment suddenly become single-stranded within a very narrow range of denaturing conditions. Because of this distinctive quality of DNA when placed in denaturing gel, it is possible to discern differences in DNA sequences or mutations of various genes. PCR amplification of DNA extracted from mixed MC with PCR primers specific for 16S rRNA gene fragments of Bacteria and Archaea, and 18S rRNA gene fragments of Eukaryotes results in mixtures of PCR products. Because these amplicons all have the same length, they cannot be separated from each other by agarose gel electrophoresis. However, sequence variations (i.e. differences in GC content and distribution) between different microbial rRNAs result in different denaturation properties of these DNA molecules. The result of this denaturation is band patterns (Figures 1,2,4,5) that can be analyzed with specific Software such as the Molecular Analysis Fingerprinting ${ }^{\circledR}$ Software that calculates percent similarity coefficient and dendrograms based on the images of the gels.

The DDGE methodology has been widely used to provide rapid, comparative analyses of apparent diversity of MC in a variety of environments (Muyzer \& Smalla, 2004). DGGE banding patterns can be used to visualize variations in microbial genetic diversity and provide a rough estimate of the richness and abundance of predominant MC members. Recently, several studies have shown that DGGE of functional genes (e.g. genes involved in sulfur reduction, nitrogen fixation, and ammonium oxidation) can provide information about microbial function and phylogeny simultaneously. DDGE gives information about changes in the numerically dominating bacterial populations. Further, individual bands of interest can be excised from the gel for cloning or direct sequence analysis (Muyzer \& Smalla, 2004). However, because this approach relies on PCR amplification with its potential biases (Ishii \& Fukui, 2001) and on visualization of resultant PCR products on gels, it is not quantitative and also likely underestimates true
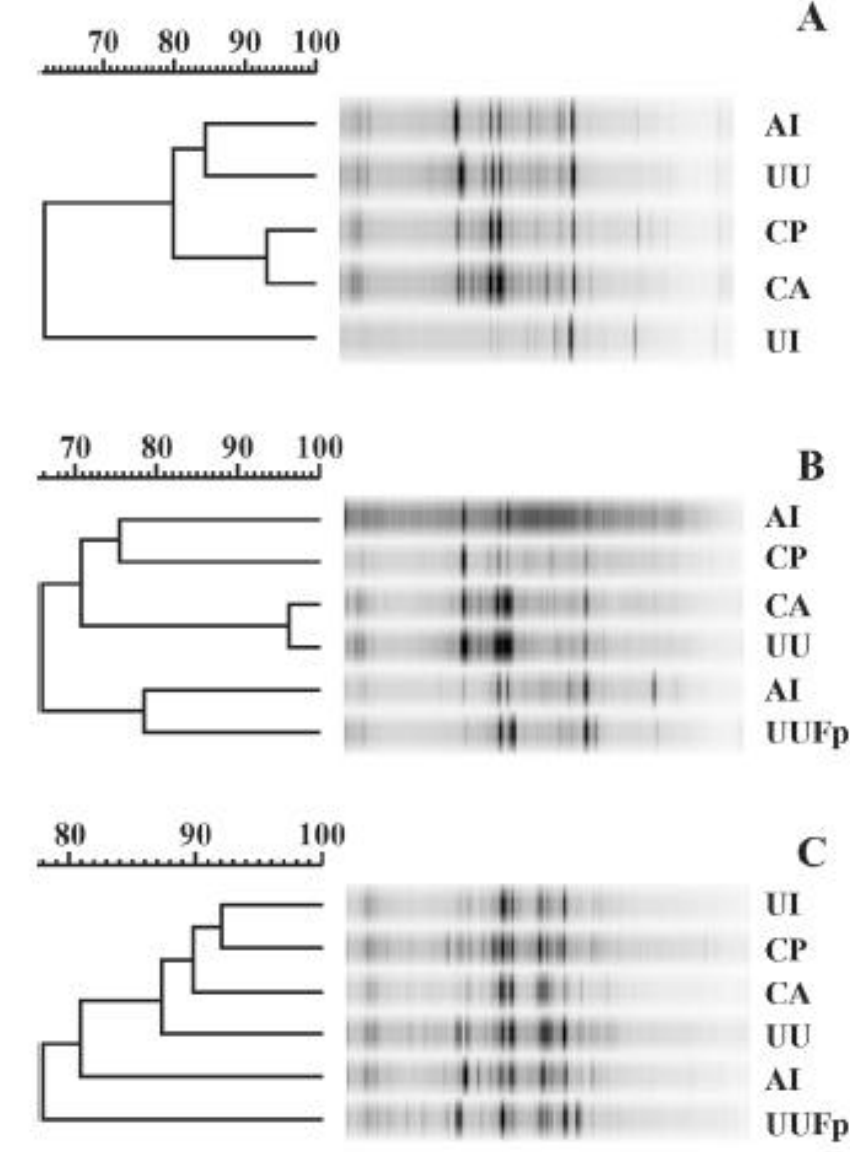

Figure 1 - Denaturing gradient gel electrophoresis of A) duodenal, B) ileal, and C) cecal microbial communities from broiler chickens at $19 \mathrm{~d}$ of age (pre-challenge). Relative similarity of band patterns is indicated by their grouping on the dendogram and the percentage similarity coefficient (bar). $\mathrm{UU}=$ unmedicateduninfected control; UUFp = unmedicated-uninfected floor pen control; UI = unmedicated-infected control; $\mathrm{AI}=\mathrm{BMD}^{\circledR}$ at $50 \mathrm{~g} /$ ton and monensin $\left(\operatorname{Coban}^{\circledR}\right)$ at $90 \mathrm{~g} / \mathrm{t} ; \mathrm{CP}=$ essential oil blend Crina ${ }^{\circledR}$ Poultry, and $\mathrm{CA}=$ essential oil blend Crina ${ }^{\circledR}$ Alternate. Source: Hume et al. (2006).

diversity in complex ecosystems like the GIT, because taxa present only in low abundance can go undetected.

Temperature gradient gel electrophoresis (TGGE) is another electrophoretic method for separation of DNA or RNA that rely on temperature dependent changes in structure, instead of chemical gradients (Muyzer \& Smalla, 2004). The original method was DGGE, which is almost identical. The same electrophoretic equipment used for analysis of proteins can be used for these methods. Since a gradient of denaturant and a gradient of temperature are linearly related, the two techniques are, from a theoretical standpoint, almost identical. Thus, it stands to reason that 


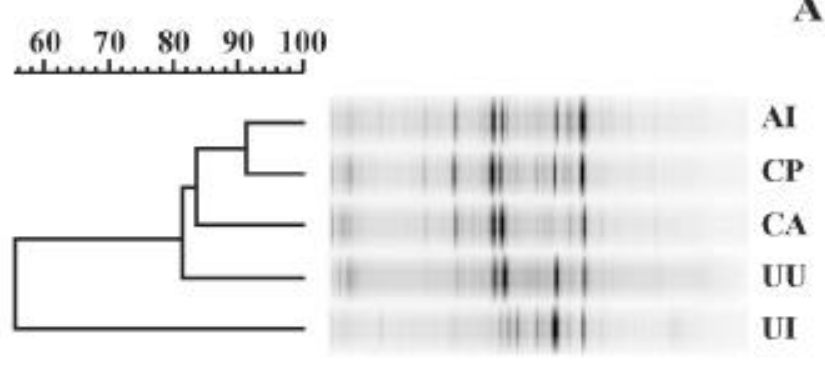

B
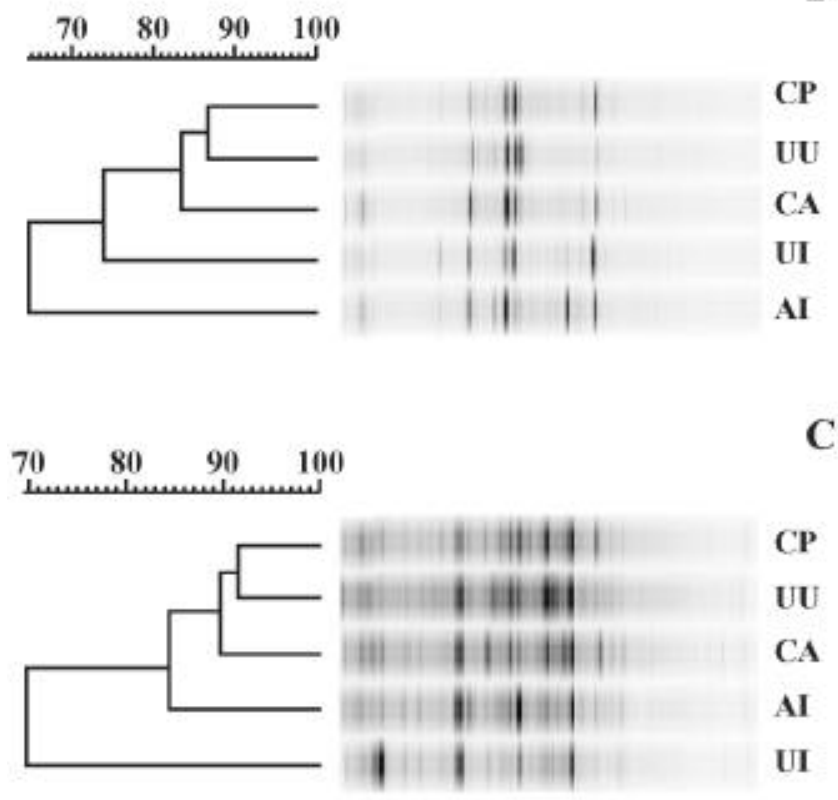

Figure 2 - Denaturing gradient gel electrophoresis of A) duodenal, B) ileal, and C) cecal microbial communities from broiler chickens at $26 \mathrm{~d}$ of age (post-challenge) and 7 days after mixed Eimeriaspp. oral infection. Relative similarity of band patterns is indicated by their grouping on the dendogram and the percentage similarity coefficient (bar). $\mathrm{UU}=$ unmedicateduninfected control; $\mathrm{UI}=$ unmedicated-infected control; $\mathrm{AI}=\mathrm{BMD}^{\circledR}$ at $50 \mathrm{~g} /$ ton and monensin $\left(\mathrm{Coban}^{\circledR}\right)$ at $90 \mathrm{~g} / \mathrm{t} ; \mathrm{CP}=$ essential oil blend Crina ${ }^{\circledR}$ Poultry, and $\mathrm{CA}=$ essential oil blend Crina ${ }^{\circledR}$ Alternate. Source: Hume et al. (2006).

understanding TGGE would best be accomplished by first considering the principles underlying DGGE. Commercial equipment for DGGE is available from Bio-Rad, INGENY and CBS Scientific; a system for TGGE is available from Biometra (Muyzer \& Smalla, 2004).

The DGGE and TGGE typically probe the entire community, including minority populations, by direct analysis of total community DNA, but they generally do not provide high-resolution identification of the populations present and do not focus on minority populations. The electrophorectic methods DGGE and TGGE are reported to be sensitive enough to represent only bacteria that make up greater than $1 \%$ of the total bacterial community.

\section{Non-16S rRNA-based profiling techniques}

These techniques include profiling of bacterial cellular fatty acids and determining community $\mathrm{G}+\mathrm{C}$ content. These methods are independent of PCR amplification and thus provide a sense of relative abundance of bacterial populations, though only at low resolution. The MC cannot be characterized phylogenetically by these methods and, therefore, they need validation by $16 \mathrm{~S}$ rRNA approaches.

GC fractionation of total community DNA has been widely used in poultry research to compare MC structures in GIT of broilers (Apajalahti et al., 1998, 2001, 2002, Parker et al., 2006). The output from this approach is a fractionated profile of the entire community that indicates relative abundance of DNA as a function of $\mathrm{G}+\mathrm{C}$ content and inferential information regarding the taxa comprising the community. In addition, this technique physically fractionates total community DNA into aliquots that represent different $\mathrm{G}+\mathrm{C}$ contents. These highly purified fractions are of high molecular weight and thus are suitable for additional molecular manipulations, including PCR amplification, DGGE analysis, and cloning. Its primary limitation is the low resolution that does not indicate the number or ident ity of different taxa in a particular $\mathrm{G}+\mathrm{C}$ fraction.

The limitations of DDGE and GC fractionation of total community DNA techniques can be overcome by combining methods. Holben et al. (2004) combined two mechanistically different community analysis methods, the GC fractionation and DGGE (GC-DGGE) with phylogenetic analysis of DNA and 16S rRNA gene sequences to obtain information on minority populations or taxa in the GIT that were not detected by a typical random cloning survey of the same community due to low abundance. The initial fractionation of total community DNA based on $\mathrm{G}+\mathrm{C}$ content effectively reduces the complexity of the community DNA mixture being analyzed such that the total diversity within each fraction can be more effectively assessed. Additionally, by cloning and sequencing DGGE bands from individual fractions, it is possible to gain insight into the identity of specific taxa of interest (Holben et al., 2004).

\section{Quantification of 16S rRNA and its encoding genes}

The PCR-based methods do not provide quantitative data because of amplification biases. Dot-blot hybridization can be used to determine the relative amounts of rRNA from specified bacterial groups or species. Quantification by 
dot-blot hybridization is very accurate, as rRNA is directly targeted without any amplification procedure. Recently, an oligonucleotide database called ProbeBase was developed. This database has proved to be very useful in the search for existing probes when studying a target group of interest as it is now possible to link probe information to published literature (http://www.microbialecology.net/probebase/; Loy et al., 2003). A drawback of dot-blot hybridization concerns its limited sensitivity (Zoetendal \& Mackie, 2005).

Real-time PCR techniques (qrt-PCR) are currently very popular, as they combine the sensitivity of regular PCR with accurate quantification. Therefore, sequences that are of a very low concentration in GIT samples can best be quantified using this approach. However, the technique is time consuming for complex ecosystems like the GIT, as primers and PCR conditions have to be developed and validated for each group of sequences or OUT of interest. Competitive (RT-)PCR and most probable number (MPN)-PCR are other means of quantifying the bacterial $16 \mathrm{~S}$ rRNA gene in GIT samples; however, after the introduction of the qrt-PCR technology, their application has drastically decreased (Zoetendal \& Mackie, 2005).

Fluorescence in situ hybridization (FISH) is another method to quantify bacterial cells using $16 \mathrm{~S}$ rRNA-targeted oligonucleotide probes combined with epifluorescent light microscopy, confocal laser microscopy or flow cytometry (Zoetendal \& Mackie, 2005). Enumeration of bacteria by FISH is based on cell counts and consequently is more accurate for quantification. However, at present, the lowest level of detection is 106 cells per gram of faeces, which is less sensitive than qrt-PCR. FISH of intestinal bacteria has been mainly focused on faeces from humans, and probes targeting many phylogenetic groups of bacteria have already been developed and validated.The major disadvantages of FISH are that only a few probes can be used per analysis and that probe development is dependent on the $16 \mathrm{~S}$ rRNA gene sequences deposited in the different databases. Other difficulties concerning FISH include the number of ribosomes per cell, the accessibility of the target and the permeability of the bacterial cell (Zoetendal \& Mackie, 2005).

DNA microarray technology and diversity arrays can also be used to assess MC composition in the GIT of poultry. Community Genome Arrays (CGAs) contain pure whole genomic DNA from many different formally characterized reference organisms as well as environmental isolates. Work evaluating the specificity, sensitivity, quantitation potential, and applicability of CGAs is ongoing (Krause et al., 2004). On the other side, Phylogenetic Oligonucleotide Arrays (POAs) contain 16S rDNA oligonucleotide probes targeting bacteria at different taxonomic levels (e.g., kingdom, phyla, family, genus, species, and even strains). However, achieving hybridization specificity has been a major challenge in the ongoing development of POAs because of the potential crosshybridization of oligonucleotide probes to 16S rRNA genes from non-targeted organisms. So far, work in this area has focused on oligonucleotide probe attachment to glass slides and the optimization of hybridization conditions for achieving single nucleotide mismatch discrimination (specificity). Currently, the most promising way to discriminate between specific and non-specific hybridization is the determination of thermal dissociation

Table 2 - Methods used or proposed to determine microbe functionality in gut environments

\begin{tabular}{|c|c|c|c|}
\hline Approach & Target & Outcome experiment & Main limitations \\
\hline Microarray technology & $\begin{array}{l}\text { Genes encoding for specific enzymes } \\
\text { responsible of metabolic pathways }\end{array}$ & $\begin{array}{c}\text { Gene sequences } \\
\text { and expression levels }\end{array}$ & $\begin{array}{c}\text { Cost, data interpretation, } \\
\text { linking function with specific } \mathrm{MC}\end{array}$ \\
\hline BAC vector cloning & Genomic DNA & Gene sequences & $\begin{array}{c}\text { Bias in NA extraction and cloning; } \\
\text { laborious }\end{array}$ \\
\hline $\begin{array}{l}\text { Suppressive subtractive } \\
\text { hybridization }(\mathrm{SSH})\end{array}$ & Genomic DNA & Unique gene sequences & $\begin{array}{l}\text { Bias in NA extraction, } \\
\text { sensitive for false-positives }\end{array}$ \\
\hline In situ isotope tracking & Labelled biomarkers & $\begin{array}{l}\text { Identification of substrate- } \\
\text { utilizing microbes }\end{array}$ & $\begin{array}{l}\text { Only suitable for } \\
\text { simplepathways }\end{array}$ \\
\hline Probe-based cell sorting & Genomic DNA, plasmid DNA, rRNA & $\begin{array}{l}\text { Sorted cells containing } \\
\text { certain gene sequences }\end{array}$ & Dependent on sequence data \\
\hline (R-)IVET & Promoter regions & Identification of induced promoters & Cultivation required \\
\hline Proteomics & Proteins, enzymes & $\begin{array}{l}\text { Identify specific metabolites } \\
\text { or proteins }\end{array}$ & $\begin{array}{l}\text { Complex analyses and link to } \\
\text { specific MC in situ }\end{array}$ \\
\hline
\end{tabular}

Source: Adapted from Zoetendal \& Mackie, 2005. 
curves for each probe-target duplex (El Fantroussi et al., 2003). Other approaches that minimize detection of falsepositives include applying multiple probes for specific targets on the DNA microarray, although the problem with such approaches is the difficulty of explaining the outcome (Zoetendal \& Mackie, 2005).

\section{Methods to identify functionality}

To determine the MC functionality in the gut ecosystem is the second step to understand these ecological systems and be able to manipulate them adequately. Research on poultry intestinal MC functionality is still scarce. Many gut microbes cannot be cultured, and even when they are cultured, it is difficult to determine if a certain microbe will have the same function in the host (in situ) as it is able to show it in the culture. The presence of DNA sequences of a MC in a GIT sample, even in large numbers, does not indicate that this particular MC is active or play a role in that specific ecosystem, since many of its members could be dead. Additionally, it is not easy to elucidate the function of a particular MC when interacting with other $\mathrm{MC}$ in the host environment. Some of the common methods used to establish functionality in molecular microbial ecology are described in Table 2. Currently, many MC have been sequenced, but most microbes have not been isolated, and consequently the full extent of the GIT microbial diversity cannot be accessed by genome sequencing and comparative genomics. Consequently, to estimate functionality in a niche where member interaction affects function is very difficult.

\section{DNA microarray technology}

Glass-based microarrays have been used for analysis of the composition and also to determine function and dynamics of any given MC. The designed probes encompass the variation in $>14,000$ known microbial functional genes involved in nitrogen, carbon, and sulfur cycling processes, as well as methane oxidation and reduction, organic contaminant degradation and metals reduction and resistance. Additionally, more exhaustive and detailed probe sets may be used to create arrays with multiple probes for any given target gene. In this way is possible to robustly characterize microbial functional diversity between samples for a particular process using DNA or RNA hybridizations. Two of the main problems regarding DNA microarray analysis are hybridization specificity and quantification of signals. Often, very complicated software programs are involved in statistically determining signal-noise ratios (Zoetendal \& Mackie, 2005).
Another method to obtain genetic and functional information about uncultured microbes is random cloning of DNA from environmental samples using bacterial artificial chromosome (BAC) or fosmid vectors (Zoetendal \& Mackie, 2005). This technique, frequently called metagenomics, provides direct access to large genomic fragments ( $\sim 100 \mathrm{~kb}$ for BACs, $\sim 40 \mathrm{~kb}$ for fosmids) that are isolated directly from microbes in natural environments. The information on these fragments can be used to link $16 \mathrm{~S}$ rRNA sequences and functional genes, from which the latter can be characterized experimentally by, for example, overexpression in E.coli or other hosts. This constitutes the main limitation for BAC's cloning because only 2-3\% of clones contain a $16 \mathrm{~S}$ rRNA gene. The genome of strains belonging to the same microbial species may differ by as much as $20 \%$, and consequently the metagenomic libraries are extremely large in order to cover the total diversity. To reduce the number of clones required it is possible to use techniques such as DNA microarray analysis and subtractive hybridization.

Methods of subtractive hybridization such as representational difference analysis (RDA) and suppressive subtractive hybridization (SSH) display the difference between two organisms by excluding genes in common. These techniques basically include the hybridization of tester DNA that contains the target DNA fragments of interest with excessive driver DNA as a reference. Latter on the unhybridized target DNA is separated from hybridized common sequences (Zoetendal \& Mackie, 2005).

To determine the function and metabolism of the MC in the environment ( in situ), it is possible to use isotopically (stable or radioactive) labeled substrates. The isotopes of a substrate can be traced back by extracting biomarkers, such as DNA or lipids, or by combining microautoradiography and in situ hybridization. The method is complex, expensive and not difficult to interpret when several MC can be involved on using the same labeled substrate. No studies using this method on intestinal microbial ecology were found at the moment of the present review.

Many MC are either not active or dead in some parts of the intestine and do not play important roles in those sections. Probe-based cell sorting with flow cytometry are also useful to divide the MC cells into active, injured or dead cell populations and determine the ones that really have impact in the specific intestinal ecosystem. Another method to detect the activity of some MC is to measure the expression of functional genes or proteins. This can be done with transcriptional profiling, qrt-RT-PCR, competitive RT-PCR, 
FISH, in vivo expression technology (IVET) or the resolvasebased IVET (Zoetendal \& Mackie, 2005). The IVET methods screen for promoters that are specifically induced when bacteria are exposed to certain environmental conditions. However, both IVET techniques don't provide information about expression levels and the location at which they are induced in the GIT, but this information can be obtained using quantitative RT-PCR or other transcriptional methods in samples of each niche.

All the previous RNA-based methods offer valuable information about gene regulation on a transcriptional level, but there is always posttranscriptional regulation. Because of this, it has been proposed the application of proteomics and metabolomics to evaluate the final activity of the MC. This process is even more complex in gut diverse ecosystems with several MC producing similar proteins and metabolites (Zoetendal \& Mackie, 2005).

Impact of new methods on gut microbial ecology

The new molecular methods indicate that the majority of gut microbes has never been cultured. The gut MC are very host and GIT niche specific (Gong et al., 2002). The MC are affected by host genotype, diet, some feed additives including antibiotics, and by changes in management conditions. Most of the novel sequences from GIT samples are grouped in the low G + C Grampositive phylum. The clostridial clusters are a major component of the uncultured bacteria normally found in the GIT samples. Many of the MC can be detected with $16 \mathrm{~S}$ rRNA techniques, but this does not indicate that they are active, because many can be dead as it has been determined with FISH techniques. The predominant gut MC are relatively stable over time in healthy animals, but shifts in MC occur with ageing, especially in young and old animals, periods of starvation or intestinal insults such as coccidiosis infections. It is noteworthy that unstable MC is frequently correlated with GIT disorders. Feed additives or diets that maintain more stable MC even during periods of stress, also support better animal performance in those conditions.

The molecular techniques open a window of opportunities in manipulation of gut microflora to obtain benefits for the host. For example, it is possible to envision the genetic manipulation of commensal bacteria (Bacteroides, Lactococcus), that can help to stimulate heterologous expression of cytokines, adjuvants, antigens to modulate host immune responses.

The classification criteria for bacterial species are changing, due to the large sequence analysis of microbial genomes, and the unexpected diversity between closely- related species. Taking in consideration the new knowledge on $\mathrm{MC}$ is even more important to redefine populations as functional groups among the microflora, and according to the mechanisms by which they impact on their host. Consequently the DNA arrays, microbial genomics, proteomics and metabolomics will be more necessary in the near future.

Additionally, after learning on the importance of MC and "cross-talk" with the host mucosa, it is more important to evaluate host traits controlling microbial ecology. It is important to determine the mechanisms where different cell types (eg., epithelial cells, paneth cells, intraepithelial lymphocytes) are involved. It is also important to establish the adhesion targets and nutrients favoring selected commensals, or the products that determine the killing and suppressive molecules (eg., paneth cell constituents), cytokines or inflammatory mediators that modify these processes.

\section{Examples of applicatios on gut MC of broilers}

Our research group has used several molecular methods to study the effects of antibiotics and ionophores, EO, enzymes, and probiotics as feed additives in broilers vaccinated against coccidia and/or in challenges with pathogenic sporulated oocysts of mixed Eimeria spp. Coccidiosis is a common parasitism in poultry and one of the more common causes of enteric problems. Coccidiosis is still one of the most endemic enteric diseases in broiler production worldwide (Williams, 2005). Coccidial stress consistently has been shown to sensitize broilers to enteritis including necrotic enteritis (NE) (Van Immerseel et al., 2004; Williams, 2005). Coccidia infection causes reduced weight gain and poor feed conversion efficiency, reduced feed and water intake, increased intestinal passage time, decreased digesta viscosity and nutrient digestion, villous atrophy, intestinal leakage of plasma proteins, and increased intestinal acidity (Williams, 2005).

We used DGGE to examine the digestive microbial composition and to determine community succession in the duodena, ilea, and ceca of broilers infected with Eimeria spp. oocysts, and fed corn-soybean meal diets without feed additives or supplemented with either an antibiotic + anticoccidial $\left(\mathrm{BMD}^{\circledR}+\mathrm{Coban}^{\circledR} ; \mathrm{AI}\right)$ or two specific EO blends, Crina ${ }^{\circledR}$ Alternate $(\mathrm{CA})$ and Crina ${ }^{\circledR}$ Poultry $(\mathrm{CP})$ (DSM Nutritional Products) (Hume et al., 2006). Similar treatments were also evaluated in broilers vaccinated at first day of age against Eimeria spp. (Oviedo-Rondón et al., 2006). Although the mixed coccidia challenge was associated with the greatest relative shifts in the post-challenge MC in all three sections of the intestine, independent of the 


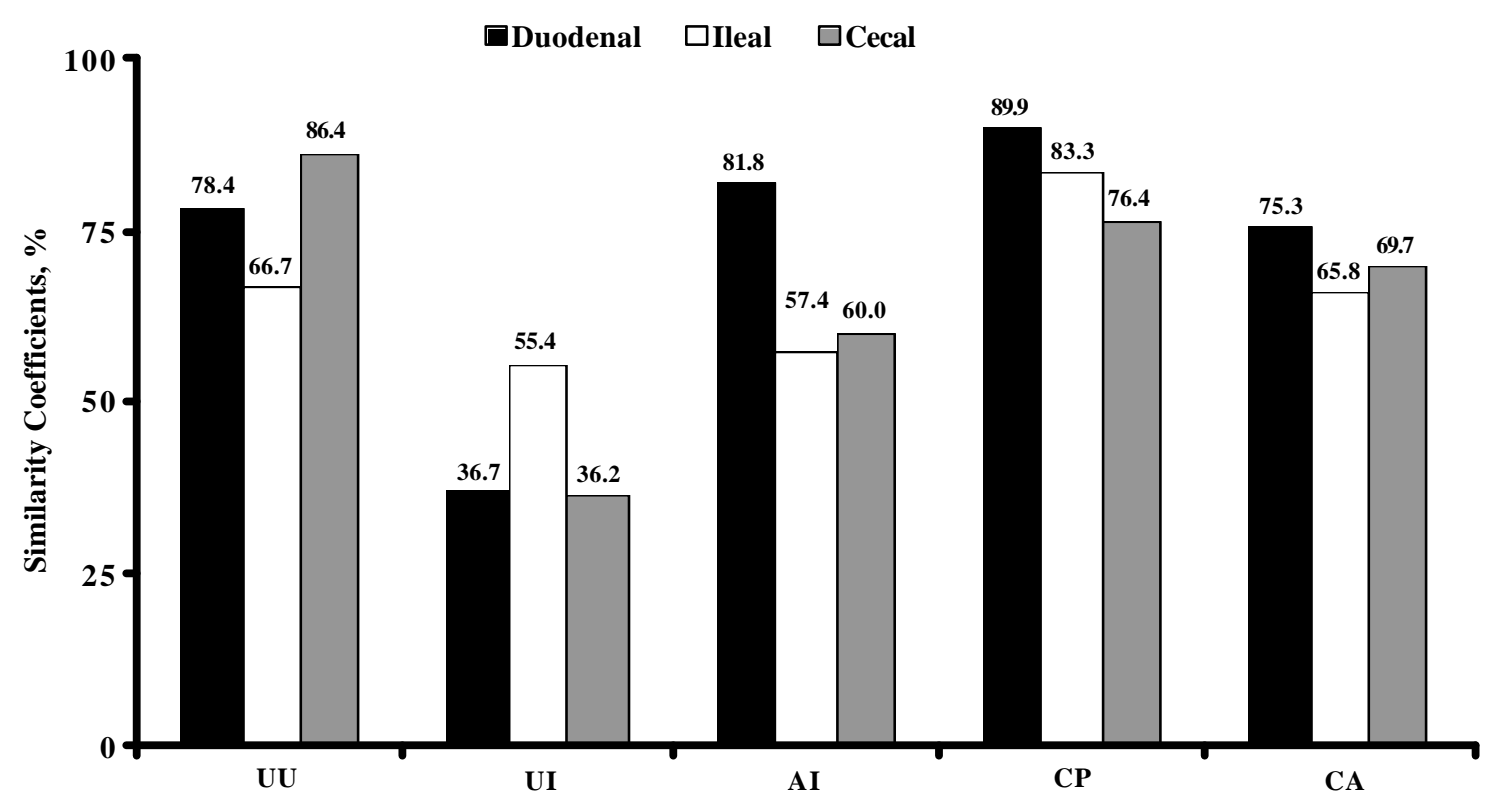

Figure 3 - Percentage similarity coefficients from comparisons of microbial communities in pre- and post-coccidia challenge samples within each treatment and intestinal compartment. UU = unmedicated-uninfected control; UI = unmedicated-infected control; $\mathrm{AI}=\mathrm{BMD}^{\circledR}$ at $50 \mathrm{~g} / \mathrm{t}\left(\right.$ Alpharma) and monensin $\left(\mathrm{Coban}^{\circledR}\right)$ at $90 \mathrm{~g} / \mathrm{t}\left(\right.$ Elanco); $\mathrm{CP}=$ essential oil blend Crina ${ }^{\circledR}$ Poultry (DSM Nutritional Products), and CA = essential oil blend Crina ${ }^{\circledR}$ Alternate (DSM Nutritional Products). Source: Hume et al. (2006).

treatment (UI) (Figures 2, 3 and 5) and, only in cecal samples (Panel $\mathrm{C}$ in Figures 2, 5) was it possible to observe a clear difference between pre- and post-challenge $\mathrm{MC}$ for all treatments as well as the effect of coccidia challenge (UI). The similarity coefficients obtained with the analyses of DGGE images (Figures 3 and 6) showed that feed additives modulate $\mathrm{MC}$ in coccidial challenges, although they do vary in their influences over MC in each intestinal compartment. Under the conditions of the present experiment the specific EO blends $\mathrm{CA}$ and $\mathrm{CP}$ appear to be effective in modulating $\mathrm{MC}$ and avoid drastic changes in $\mathrm{MC}$ after a mixed coccidia challenge. Some specific bands visualized in the gels evaluated in these experiments were candidates to search for MC co-related with differences in performance under these intestinal stress conditions. The cloning and sequencing of these individual fractions may help to identify specific taxa of interest for future manipulation (Apajalahti et al., 2004; Holben et al., 2004).

Selected electrophoretic bands of DGGE gels were extracted and cloned for identification of bacteria. The objective was to identify bacteria exhibiting dramatic population changes as a result of treatments. A bacterial tag encoded FLX amplicon pyrosequencing (bTEFAP) approach was used to perform deep and semi-quantitative diversity analysis of GIT populations (Nalian et al., 2009). Pyrosequencing and parallel sequencing of individual DNA molecules (Bosch \& Grody, 2008) allows examination of the dynamics of intestinal flora quantitatively and far more precisely than previously possible with other techniques. This bTEFAP is relatively inexpensive in terms of both time and labor due to the implementation of a novel tag priming method and an efficient bioinformatics pipeline. In 24 hours, this method is able to generate and analyze a nominal 1,000 sequences per sample. This technique gave us a good look at the microbial diversity in the digesta samples affected by treatments. Results presented in Figure 7 will be discussed in the presentation. Bioinformatic analyses linking the MC identified with ammonia producer groups are undergoing.

In the last study (Parker et al., 2007), we used GC fractionation of total community DNA to evaluate the effect of enzyme supplementation on cocci-vaccinated birds preand post-challenge. Microbial profiles described by $\mathrm{G}+\mathrm{C} \%$ were affected $(\mathrm{P} \leq 0.05)$ by both dietary $\mathrm{CP}$ level and vaccination or feed additives (Figure 8). On average, treatments infected with mixed coccidia species hosted gut $\mathrm{MC}$ characterized by higher relative abundance of bacteria in the 50 to $80 \mathrm{G}+\mathrm{C} \%$ range when the diet had either 21 or $23 \% \mathrm{CP}(P \leq 0.01)$. Cocci-vaccinated chicks supplemented 


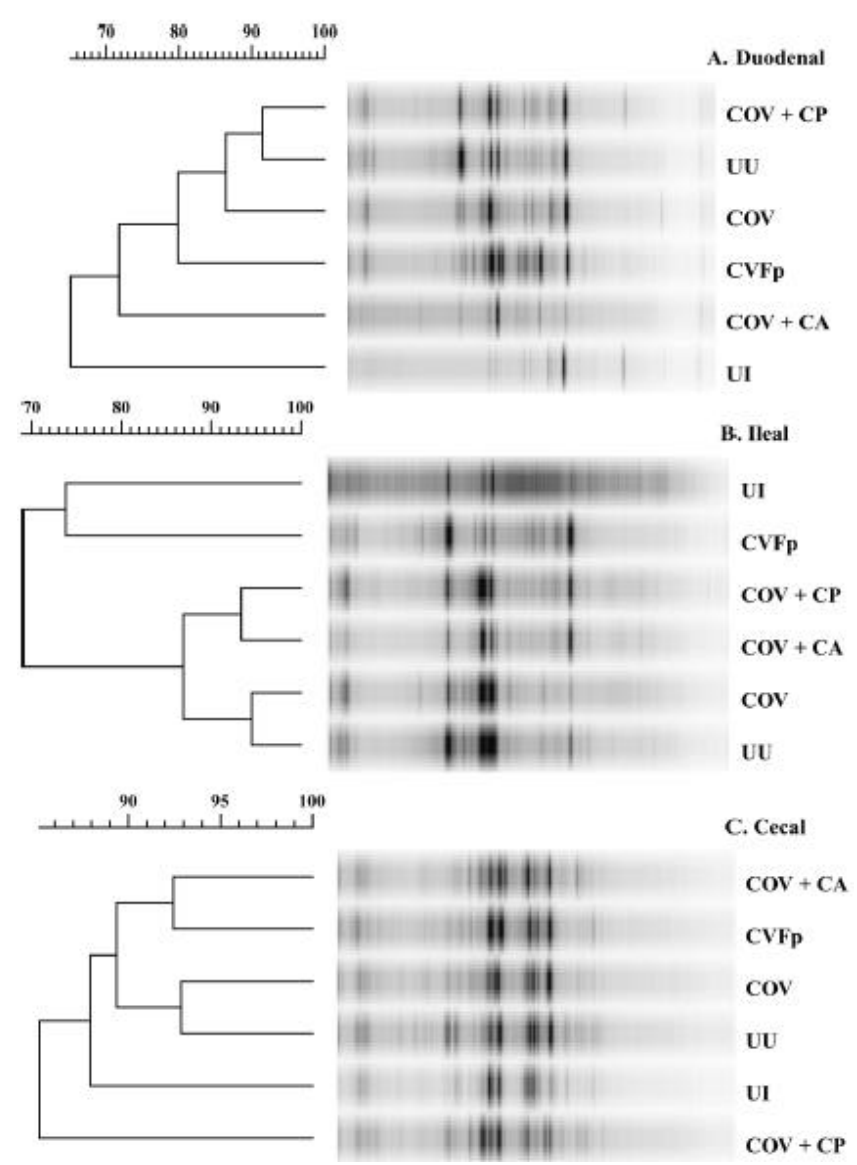

Figure 4 - Denaturing gradient gel electrophoresis of A) duodenal, B) ileal, and C) cecal microbial communities from broiler chickens at $19 \mathrm{~d}$ of age (preinfection). Relative similarity of band patterns is indicated by their grouping on the dendogram and the percentage similarity coefficient (bar). UU $=$ unmedicateduninfected control; $\mathrm{UI}=$ unmedicated-infected control; $\mathrm{COV}=$ coccidia-vaccinated with Advent ${ }^{\circledR}$ (Viridus Animal Health LLC-Novus International Inc., St. Louis, $\mathrm{MO}) ; \mathrm{CP}=$ essential oil blend Crina ${ }^{\circledR}$ Poultry; $\mathrm{CA}=$ essential oil blend Crina ${ }^{\circledR}$ Alternate; $\mathrm{CVFp}=$ coccivaccinated floor pen.

Source: Oviedo-Rondón et al. (2006).

with enzymes (COV + EC) fed diets $19 \% \mathrm{CP}$ showed very similar $\mathrm{G}+\mathrm{C} \%$ profiles related to the UU controls (Figure 8, panel A). The $t$-test comparing $\mathrm{COV}$ and $\mathrm{COV}+\mathrm{EC}$ treatments indicated that microbial profiles changed $\mathbf{P} \leq 0.001)$ due to enzyme supplementation in all $\mathrm{G}+\mathrm{C} \%$ increments except in those from 60 to $69 \%$ in chickens fed 23\% CP diets (Figure 8, panel C).

We have observed in several studies (Oviedo-Rondón et al., 2006/ Parker et al., 2007; Nalian et al., 2009) that
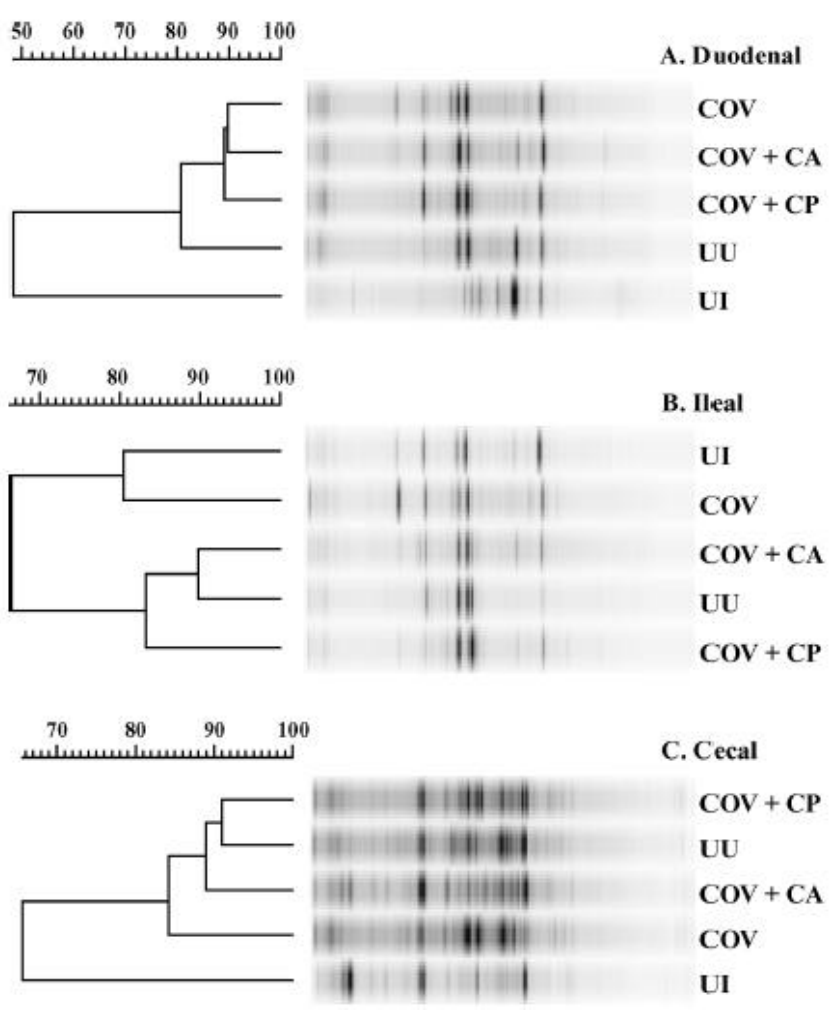

Figure 5 - Denaturing gradient gel electrophoresis of A) duodenal, B) ileal, and C) cecal microbial communities from broiler chickens $7 \mathrm{~d}$ after mixed Eimeria species infection (26 d of age). Relative similarity of band patterns is indicated by their grouping on the dendogram and the percentage similarity coefficient (bar). $\mathrm{UU}=$ unmedicated-uninfected control; UI = unmedicatedinfected control; COV = coccidia-vaccinated with Advent ${ }^{\circledR}$ (Viridus Animal Health LLC-Novus International Inc., St. Louis, $\mathrm{MO})$; $\mathrm{CP}=$ essential oil blend Crina ${ }^{\circledR}$ Poultry; CA $=$ Essential oil blend Crina ${ }^{\circledR}$ Alternate.

Source: Oviedo-Rondón et al. (2006).

vaccination against coccidia with viable oocysts by itself causes small changes on intestinal microflora (Figure 4), and that stresses and coccidia challenge result in drastic shifts in MC (Figure 4 vs Figure 5, Figure 6) that can partially be modulated with feed additives, but the response changes according to diet composition (Figure 7) even in broilers fed corn-soybean meal diets with different levels of protein (Figure 8) (Parker et al., 2007). 


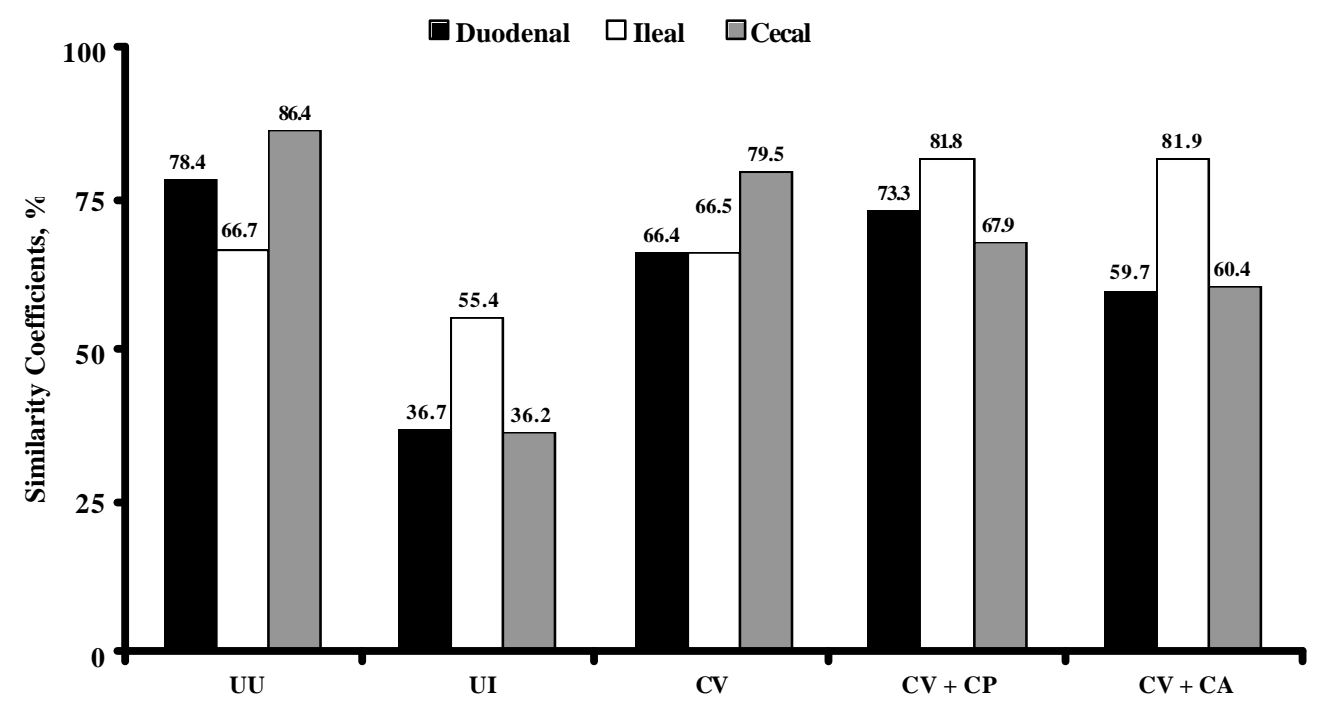

Figure 6 - Similarity coefficients (\%) comparing microbial communities in pre- and postchallenge samples within each treatment and intestinal compartment. $\mathrm{UU}=$ unmedicated-uninfected control; $\mathrm{UI}=$ unmedicated-infected control; $\mathrm{COV}=$ coccidia vaccinated with Advent (Viridus Animal Health LLC - Novus International Inc., St. Louis, MO); CP = essential oil blend Crina ${ }^{\circledR}$ Poultry; $\mathrm{CA}=$ essential oil blend Crina ${ }^{\circledR}$ Alternate. Source: Oviedo-Rondón et al. (2006).
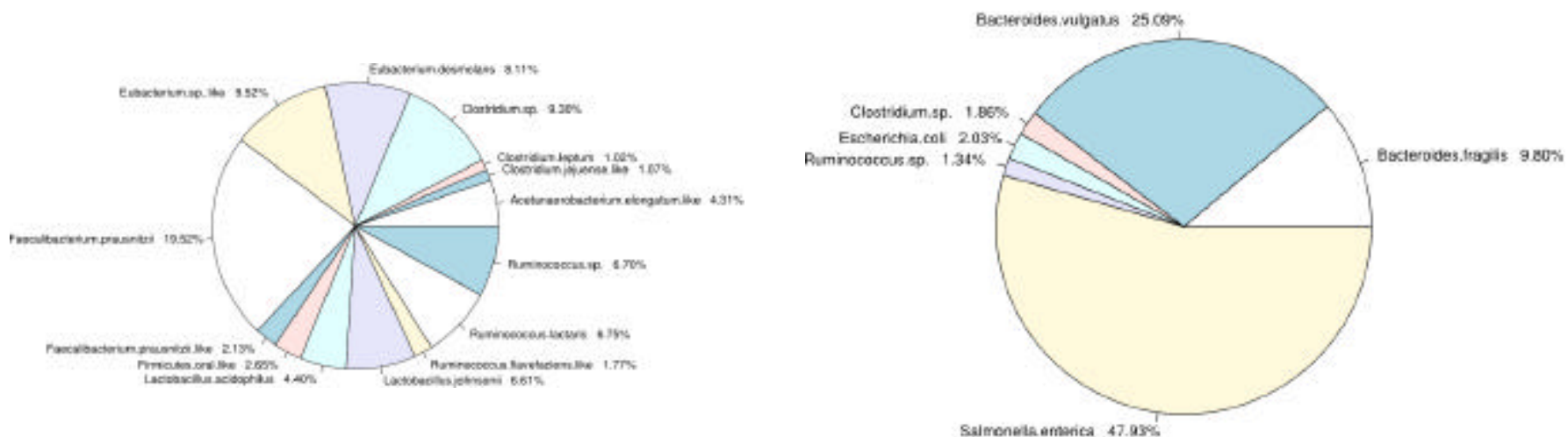

Figure 7 - Cecal microbial communities of broilers quantified and identified by bacterial tag encoded FLX amplicon pyrosequencing (bTEFAP) from selected DGGE bands observed in experiments described in Hume et al. (2006). (A) Microbial communities in ceca of chickens fed a basal corn-soybean meal diet without feed additives during the pre-challenge period. (B) Microbial communities in ceca of chickens fed a basal corn-soybean meal diet without feed additives after a challenge with mixed coccidia species (Nalian et al., 2009). 

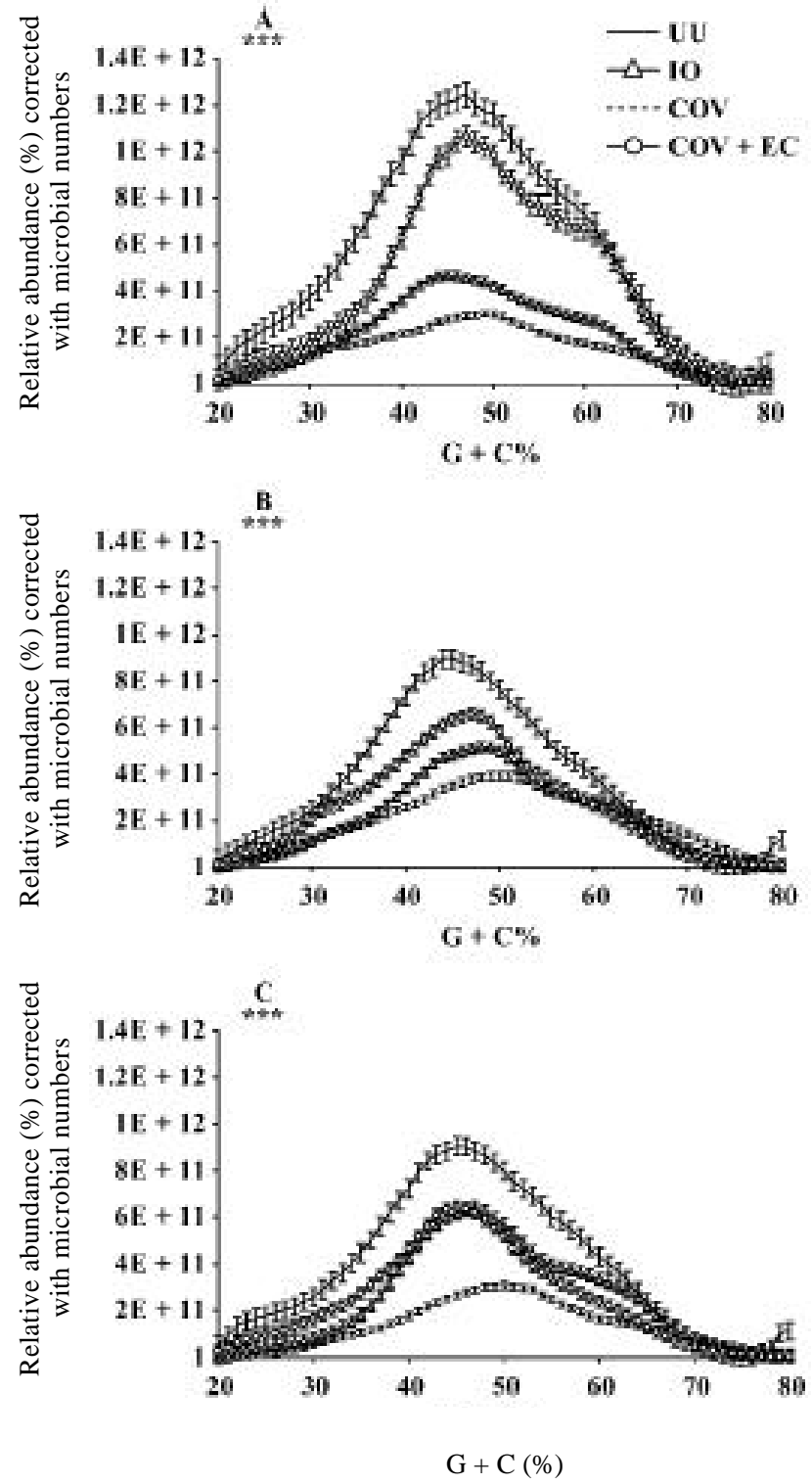

Figure 8 - The $\mathrm{G}+\mathrm{C} \%$ profile of a cecal microbial community DNA corrected with microbial numbers from 12 broilers per treatment. Treatments are compared within each dietary protein level: 19\% (panel A), $21 \%$ (panel B), and 23\% CP (panel C): $\mathrm{UU}=$ unmedicated-uninfected controls; $\mathrm{IO}=$ ionophore monensin; $\mathrm{COV}=$ coccidia vaccination; $\mathrm{COV}+\mathrm{EC}=$ coccidia vaccination + dietary enzyme supplementation (Avizyme ${ }^{\circledR} 1502$, Danisco Animal Nutrition). $* * * \operatorname{Pd} \leq 0.001$.

Source: Parker et al. (2007).

\section{Conclusions}

The understanding and description of intestinal microbial communities are very important for the development of new feed additives and appropriate manipulation of diets to improve poultry performance, health, welfare, and to reduce food borne pathogens and the environmental impact of poultry production. Molecular methods of microbial ecology are key tools to characterize these communities and establish their function in these dynamic ecosystems and their relationships with the host. Current work is mainly focused on identifying and classifying microbial communities in the different niches of gastrointestinal tract under different management, nutritional and health conditions. No much work has been done to elucidate functionality and to link it with presence of specific communities. Presently, the techniques more frequently used to assess microbial ecology are based on 16S rRNA amplification by PCR followed by DDGE analyses, and DNA sequencing for phylogenetic identification. However, in poultry research GC fractionation of total community DNA has provided important information. RTPCR and qRT-PCR are becoming more popular as quantitative methods together with techniques such as dot-blot hybridization and FISH. There are advances on microarray technology to identify microbial communities and their functionality in gastrointestinal samples. Many examples of successful application of these methods on poultry research justify their future application.

\section{Literature Cited}

ANDERSON, D.B.; McCRACKEN, V.J.; AMINOV, R.I. et al. Gut microbiology and growth-promoting antibiotics in swine. Nutrition Abstract Review Series B, v.70, p.101-108, 1999.

APAJALAHTI, J.H.; BEDFORD, M.R. Improve bird performance by feeding its microflora. World Poultry, v.15, p.20-23, 1999.

APAJALAHTI, J.H. Microbial management: a new approach to development in animal nutrition. In: INTERNATIONAL CONGRESS FOR THE FEED INDUSTRY IN SOUTHERN AFrICA, 5., 2004, Sun City. Proceedings... Sun City, South Africa: AFMA, 2004.

APAJALAHTI, J.H.; KETTUNEN, A.; BEDFORD, M.R. et al. Percent $\mathrm{G}+\mathrm{C}$ profiling accurately reveals diet-related differences in the gastrointestinal microbial community of broiler chickens. Applied Environmental Microbiology, v.67, p.5656-5667, 2001.

APAJALAHTI, J.H.; KETTUNEN, H.; KETTUNEN, A. et al. Culture-independent microbial community analysis reveals that 
inulin in the diet primarily affects previously unknown bacteria in the mouse cecum. Applied Environmental Microbiology, v.68, p.4986-4995, 2002.

APAJALAHTI, J.H.; SARKILAHTI, L.K.; MAKI, B.R. et al. Effective recovery of bacterial DNA and percent-guanine-pluscytosine-based analysis of community structure in the gastrointestinal tract of broiler chickens. Applied Environmental Microbiology, v.64, p.4084-4088, 1998

APAJALAHTI, J.H.A.; KETTUNEN, A.; BEDFORD, M.R. et al Percent $G+C$ profiling accurately reveals diet-related differences in the gastrointestinal microbial community of broiler chickens. Applied Environmental Microbiology, v.67, p.5656-5667, 2001

BAR-SHIRA, E.B.; SKLAN D.; FRIEDMAN, A. Impaired immune responses in broiler hatchling hindgut following delayed access to feed. Veterinary Immunology and Immunopatholology, v.105, n.1-2, p.33-45, 2005.

BAR-SHIRA, E.B.; FRIEDMAN, A. Ontogeny of gut associated competence in the chick. Israel Journal of Veterinary Medicine, v.60, n.2, p.42-50, 2005

BEDFORD, M.R.; SCHULZE, H. Exogenous enzymes in pigs and poultry. Nutrition Research Reviews, v.11, p.91-114, 1998.

BOSCH, J.R.; GRODY, W.W. Keeping up with the next generation: massively parallel sequencing in clinical diagnostics. Journal of Molecular Diagnostics, v.10, n.6, p.484-492, 2008.

CEBRA, J.J. Influences of microbiota on intestinal immune system development. American Journal Clinical Nutrition, v.69, p.1046S-1051S, 1999.

COLLIER, C.T., SMIRICKY-TJARDES, M.R.; ALBIN, D.M. et al. Molecular ecological analysis of porcine ileal microbiota responses to antimicrobial growth promoters. Journal of Animal Science, v.81, p.3035-3045, 2003.

COLLINS, M.D.; GIBSON, GR. Probiotics, prebiotics, and synbiotics: approaches for modulating the microbial ecology of the gut. American Journal of Clinical Nutrition, v.69, p.1052S-1057S, 1999.

DAHIYA, J.D.; HOEHLER, D.; WILKIE, A. et al. Dietary glycine concentration affects intestinal Clostridium perfringens and Lactobacilli populations in broiler chickens.Poultry Science, v. 84, p. $1875-1885,2005$.

DIBNER, J.J.; RICHARDS, J.D. Antibiotic growth promoters in agriculture: History and mode of action. Poultry Science, v.84, p.634-643, 2005.

DIBNER, J.J.; RICHARDS, J.D. The digestive system: challenges and opportunities. Journal Applied of Poultry Research, v.13, p. 86-93, 2004

EL FANTROUSSI, S.; URAKAWA, H.; BERNHARD, A.E. et al. Direct profiling of environmental microbial populations by thermal dissociation analysis of native rRNAs hybridized to oligonucleotide microarrays. Applied Environmental Microbiology, v.69, p.2377-2382, 2003.

ENGBERG, R.M.; HEDEMANN, M.S.; LESER, T.D. et al. Effect of zinc bacitracin and salinomycin on intestinal microflora and performance of broilers.Poultry Science, v.79, p.1311-1319, 2000.

EWING, W.N.; COLE, D.J.A. The living gut: an introduction to micro-organisms in nutrition. Context, Dungannon, Ireland. 1994.

FULLER, R.; PERDIGÓN, G. Gut flora, nutrition, immunity and health. Ames: Blackwell Publishing, 2003.

GIBSON, GR.; ROBERFROID, M.B. Dietary modulation of the human colonic microbiota: introducing the concept of prebiotics. Journal of Nutrition, v.125, p.1401-1412, 1995.

GONG J.; FORSTER, R.J.; YU, H. et al. Diversity and phylogenetic analysis of bacteria in the mucosa of chicken ceca and comparison with bacteria in the cecal lumen. FEMS Microbiology Letters, v.208, p.1-7, 2002.

GUO, F.C.; WILLIAMS, B.A.; KW AKKEL, R.P. et al. Effects of mushroom and herb polysaccharides, as alternatives for an antibiotic, on the cecal microbial ecosystem in broiler chickens. Poultry Science, v.83, p.175-182, 2004.

HAYS, V.W. Effects of antibiotics. In: Pearson, A.M.; Dutson, T.R. (Eds.) Growth regulation in farm animals. Advances in meat research. New York: Elsevier Applied Science, 1991. v.7, p.299-320.

HOLBEN, W.E.; FERIS, K.P.; KETTUNEN, A. et al. GC fractionation enhances microbial community diversity assessment and detection of minority populations of bacteria by denaturing gradient gel electrophoresis. Applied Environmental Microbiology, v.70, n.4, p.2263-70, 2004.

HUGENHOLTZ, P.; GOEBEL, B.M.; PACE, N.R. Impact of culture-independent studies on the emerging phylogenetic view of bacterial diversity. Journal of Bacteriology, p.4765-4774, 1998.

HUGHES, J.B.; HELLMANN, J.J.; RICKETTS T.H. et al. Counting the uncountable: statistical approaches to estimating microbial diversity. Applied Environmental Microbiology, v.67, p.4399-4406, 2001.

HUME, M.E.; CLEMENTE-HERNÁNDEZ, S.; OVIEDO-RONDÓN, E.O. Effects of feed additives and mixed Eimeria species infection on intestinal microbial ecology of broilers. Poultry Science, v.85, p.2106-211, 2006.

HUME, M.E.; KUBENA, L.F.; EDRINGTON, T.S. et al. Poultry digestive microflora biodiversity as indicated by denaturing gradient gel electrophoresis. Poultry Science, v.82, n.7, p.1100-1107, 2003.

ISHII, K.; FUKUI, M. Optimization of annealing temperature to reduce bias caused by a primer mismatch in multitemplate PCR. Applied Environmental Microbiology, v.67, p.3753-3755, 2001

KNARREBORG, A.; SIMON, M.A.; ENGBERG, R.M. et al. Effects of dietary fat source and subtherapeutic levels of antibiotic on the bacterial community in the ileum of broiler chickens at various ages. Applied Environmental Microbiology, v.68, n.12, p.5918-24, 2002.

KORVER, D.R. Overview of the immune dynamics of the digestive system. In: ANNUAL CAROLINA POULT RY NUTRITION CONFERENCE, 32., 2005. Proceedings... Sheraton Imperial Hotel, 2005. p. 89-100

KRAUSE, D.O.; SMITH, W.J.; MCSWEENEY, C.S. Use of community genome arrays (CGAs) to assess the effects of Acacia angustissima on rumen ecology. Microbiology, v.150, n.9, p.2899-2909, 2004

LAN, P.T.; SAKAMOTO, M.; BENNO Y. Effects of two probiotic Lactobacillus strains on jejunal and cecal microbiota of broiler chicken under acute heat stress condition as revealed by molecular analysis of 16S rRNA genes. Microbiol Immunology, v.48, n.12, p.917-929, 2004

LANGHOUT, P. New additives for broiler chickens. Feed Mix Special: Alternatives to antibiotics. 2000. p.24-27.

LEE, K.-W.; EVERTS, H.; BEYNEN, A.C. Blending essential oils oils in broiler nutrition. International Journal of Poultry Science, v.3, p.738-752. 2002.

LEE, K.-W.; EVERTS, H.; KAPPERT, H.J. et al. Effects of dietary essential oil components on growth performance, digestive enzymes and lipid metabolism in female broiler chickens. British Poultry Science, v.44, p. 450-457. 2003.

LU, J.; SANCHEZ, S.; HOFACRE, C. et al. Evaluation of broiler litter with reference to the microbial composition as assessed by using 16S rRNA and functional gene markers. Applied Environmental Microbiology, v.69, n.2, p.901-908, 2003.

MARSH, T.L.; SAXMAN, P.; COLE, J. et al. Terminal restriction fragment length polymorphism analysis program, a web-based research tool for microbial community analysis. Applied Environmental Microbiology, v.66, p.3616-3620, 2000.

Martin, A.P. Phylogenetic approaches for describing and comparing the diversity of microbial communities. Applied Environmental Microbiology, v.68, p.3673-3682, 2002. 
MITSCH, P.; ZITTERL-EGLSEER, K.; KÖHLER, B et al. The effect of two different blends of essential oil components on the proliferation of Clostridium perfringens in the intestines of broiler chickens. Poultry Science, v.83, p.669-675. 2004.

MUYZER, G.; SMALLA, K.Application of denaturing gradient gel electrophoresis (DGGE) and temperature gradient gel electrophoresis (TGGE) in microbial ecology. Journal Antonie van Leeuwenhoek, v.73, n.1, p.127-141, 1998.

NAIDO, A.S.; BIDLACK, W.R.; CLEMENS, R.A.Probiotic spectra of lactic acid bacteria ( $L A B)$. Critical Reviews in Food Science and Nutrition, v.38, p.13-126, 1999.

NALIAN, A.; OVIEDO-RONDÓN, E.O., DOWD, S. et al. Effects of essential oil blends on intestinal microbiota of broilers challenged with mixed Eimeria species (In press) 2009.

NISBET, D.J.; CORRIER, D.E.; RICKE, S.C. et al.Cecal propionic acid as a biological indicator of the early establishment of a microbial ecosystem inhibitory to Salmonella in chicks. Anaerobe, v2, p.345-350, 1996.

OVIEDO-RONDÓN, E.O.; CLEMENTE-HERNANDEZ, S.; WILLIAMS, P. et al. Responses of broilers vaccinated against coccidia to essential oil blends supplementation: live performance in a 49 production period. Journal of Applied Poultry Research, v.14, p.657-664, 2005.

OVIEDO-RONDÓN, E.O. The role of nutrition in the cause and prevention of gastrointestinal perturbation. In: ACPV Workshop "enteric diseases of poultry: the evolving challenges and new developments", 2006, Sacramento. Proceedings... Sacramento, California: American College of Poultry Veterinarians, 2006.

OVIEDO-RONDÓN, E.O.; HUME, M.E.; HERNÁNDEZ, C. et al. Intestinal microbial ecology of broilers vaccinated and challenged with mixed Eimeria species, and supplemented with essential oil blends. Poultry Science, v.85, p.854-860, 2006.

PARKER, J.; OVIEDO-RONDÓN, E.O.; CLEMENTEHERNÁNDEZ, S et al. Enzymes as feed additive to aid in responses against Eimeria spp in coccidia vaccinated broilers fed corn-soybean meal diets with different protein levels. Poultry Science, v.86, p.643-653, 2007.

PATTERSON, J.A.; BURKHOLDER, K.M. Application of prebiotics and probiotics in poultry production. Poultry Science, v.82, p.627-631, 2003

RASKIN, L.; CAPMAN, W.C.; SHARP, R. et al. Molecular ecology of gastrointestinal ecosystems. In: MACKIE, R.I.; WHITE,
B.A.; ISAACSON, R.E. (Eds.) Gastrointestinal microbiology. New York: Chapman and Hall, 1997. v.2, p.243-298.

SAVAGE, D.C. Microbial ecology of the gastrointestinal tract. Annual Reviews in Microbiology, v.31, p.107-133, 1977.

THOMKE, S.; ELWINGER, K. Growth promotants in feeding pigs and poultry. III. Alternatives to antibiotic growth promotants. Annais Zootechnia, v.47, p.245-271, 1998.

THOMPSON, K.; BURKHOLDER, K.; PATTERSON, J. et al. Microbial ecology shifts in the ileum of broilers during feed withdrawal and dietary manipulations. Poultry Science, v.87, p.1624-1632, 2008.

THOMPSON, K.L.; APPLEGATE, T.J. Nutrients, nutritional state and small intestinal microbiota. In: NORTH CAROLINA POULTRY NUTRITION CONFERENCE, S.L., 2005. Proceedings... S.L.: 2005. p.23-37.

TORSVIK, V.; DAAE, F.L.; SANDAA, R.A.et al. Novel techniques for analyzing microbial diversity in natural and perturbed environments. Journal of Biotechnology, v.64, p.53-62, 1998.

van der WIELEN, P.W.; KEUZENKAMP, D.A.; LIPMAN L.J. et al. Spatial and temporal variation of the intestinal bacterial community in commercially raised broiler chickens during growth. Microbial Ecology, v.44, n.3, p.286-293, 2002.

Van IMMERSEEL, F.; DE BUCK, J.; PASMANS, F. et al. Clostridium perfringensin poultry: an emerging threat for animal and public health. Avian Pathology, v.33, p.537-549, 2004.

VAUGHAN, E.E.; SCHUT, F; HEILIG GH.J. et al. A molecular view of the intestinal ecosystem. Current Issues Intestinal Microbiology, v.1, p.1-12, 2000.

WARD, D.M. Molecular probes for analysis of microbial communities. In: CHARACKLIS, W.G; WILDERER, P.A. (Eds.) Structure and function of biofilms. New York: John Wiley \& Sons, 1989, p.145-163.

WILLIAMS, R.B. Intercurrent coccidiosis and necrotic enteritis of chickens: rational, integrated disease management by maintenance of gut integrity. Review Avian Pathology, v.34, n.3, p.159-80, 2005 .

ZOETENDAL, E.G; MACKIE, R.I. Molecular methods in microbial ecology. In: TANNOCK, G.W. (Ed.) Probiotics and prebiotics : scientific aspects. Dunedin, New Zealand: Caister Academic Press, University of Otago, 2005. 